\title{
Marketing Plan for Business Startups "Jamu Partnership" in Indonesia
}

\author{
Erna Setiyawati ${ }^{1}$, Rhian Indradewa ${ }^{2}$, Tantri Yanuar Rahmat Syah $^{3}$, \\ Diana Fajarwati $^{4}$
}

1,2,3,4 Department Management, Faculty Economic and Business, Esa Unggul University, Jakarta - Indonesia

\begin{abstract}
Background - Traditional Indonesian medicine is known as Jamu. Jamu as the legacy of the ancestors of the Indonesian nation has been used for generations by the community as a drink to maintain the health of the body. Jamu lovers are still dominated by baby boomers because of the stigma of bitter jamu that develop in society, especially among millennials. Jamu with a good taste becomes one of the options in the midst of the rise of contemporary drinks that do not necessarily provide health benefits. Socialization of the culture of fondness for jamu by the Government continues to be campaigned through activities of drinking jamu. Government also supports activity medical tourism services through jamu café. The lack of jamu cafes that serve delicious product an opportunity for startup who want to do business in the field of jamu. The high unemployment rate, entrepreneurial desire and the growth of jamu market that is presented further strengthen the opportunity to open a jamu partnership business. This big opportunity needs support with strong marketing activities.
\end{abstract}

Method - Using STP and Marketing Mix (NICE and 7P) strategies.

Result - This analysis can help business partnership startup companies in the field of jamu as a strategy in marketing.

Keywords: Marketing Plan, Startups, Jamu Partnership, Business Opportunity, Indonesia.

\section{INTRODUCTION}

The stigma of bitter jamu that develop in society makes jamu a healthy drink that is in demand by baby boomers.
Millennials are more likely to like the contemporary drinks served in modern cafes because of the lack of jamu that tastes good. Millennials make the café as their hangout. The products provided by PT OAM are delicious, sweet and innovative jamu. More and more partners of PT OAM, end users will easily find jamu cafes like modern cafes that serve contemporary drinks. The emergence of back to nature trend and high public awareness of the importance of healthy lifestyles make jamu as a drink that can be consumed regularly as a promotive and preventive effort. The government also supports by businesses to develop health tourism, one of which is jamu café.

Based on data from the Ministry of Manpower of the Republic of Indonesia, in 2020, Unemployment rate of 3.6 million people. Meanwhile, data from the Ministry of Industry of the Republic of Indonesia shows that the projected turnover of jamu and traditional medicine to reach $\mathrm{Rp} 20$ trillion. On the other hand, people's desire to run a business through SMEs is very high. According to Databox data in 2020, number of SMEs amounted to 64.2 million. The high unemployment rate leads to a high desire for entrepreneurship. See the prospects of jamu market, business in the field of jamu becomes an option. SMEs are also growing.

Such conditions are opportunity for PT Oesodo Alam Mandiri (PT OAM) as a startup company to build a business opportunity that provides cafes or jamu 
booths with delicious, sweet and innovative jamu products in the form of easy partnership cooperation and can use its own brand and provide training and mentoring on an ongoing basis. In order for this jamu partnership business to run well, a clear marketing planning is required.

\section{MATERIALS AND METHODS}

As a startup company, PT OAM must be able to face high risk, unstable conditions and a dynamic market environment (Harackiewicz, 2008). Many companies fail because they do not have the ability to conform to the existing business ecosystem and do not have a deep understanding of their customers' needs, preferability and price tolerance to develop attractive value propositions (Rowson, 2009). Good marketing planning is needed by PT OAM to face these challenges through the implementation of segmenting, targeting, positioning (STP) and marketing mix strategies. Marketing mix that is the focus of PT OAM as a business that makes the target market Business to Business (B2B) is to use NICE, namely Networking, Interaction, Common Interest, and Experience. However, because PT OAM is a two-sided platform business that must pay attention to its end users, PT OAM also uses 7P marketing mix strategy (Product, Price, Promotion, Place, People, Process, Physical Evidance) to help its partners. The framework used as shown in Figure 2.1 below.

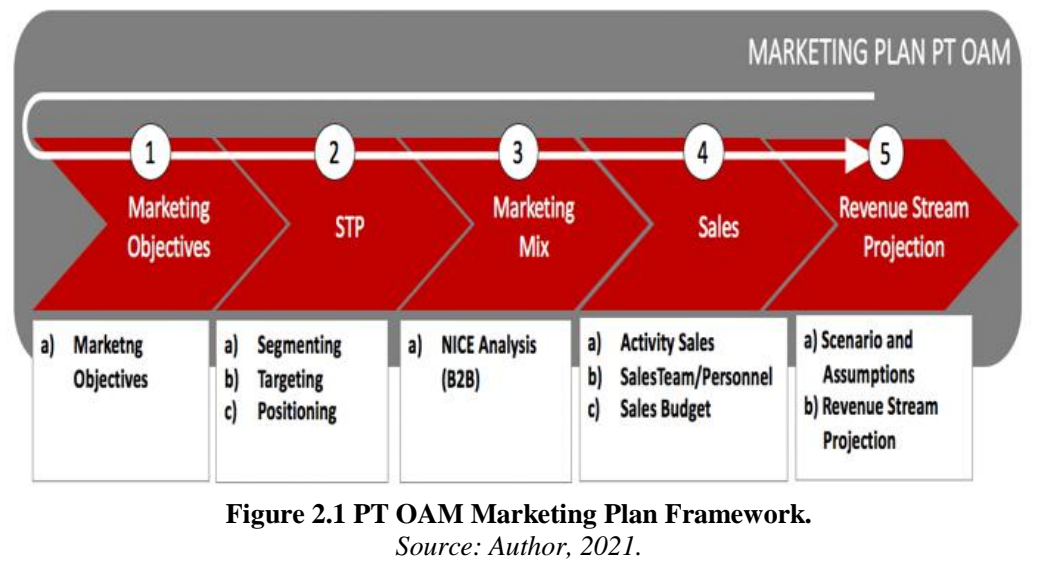

\subsection{Marketing Objective}

At the initial stage, the marketing objectives are prepared by PT OAM in accordance with the strategic objectives of the company's business. Marketing objectives are based on realistic assumptions and existing market dynamics (Calkins, 2012). In addition to succeeding in jamu partnership, PT OAM must have a good understanding of customer needs, consumption behavior, patterns and preferences (Mombeuil \& Fotiadis, 2017). In marketing activity PT OAM not only sell the product and partnership, but also create new innovation in product development (Arifin et al., 2019).

\subsection{Segmenting, Targeting, Positioning}

In the context of $\mathrm{B} 2 \mathrm{~B}$, companies may decide to group consumers by demographic variables (i.e., customer size), geographic location, usage rate, or industry characteristics. PT OAM determines the target market in accordance with the predetermined segmentation. The target market is well managed in order to achieve an efficient and effective market. Determination of PT OAM's target market is accompanied by consideration of conformity between the needs of segments and the ability of products or partnerships in providing the desired value (Morris \& LaForge, 2002). Once PT OAM's target market is determined, the company's next step is to develop a product positioning or 
partnership for that target market. PT OAM classify STP very clearly, that is an important to get market share and product positioning (Andayani et al., 2020).

\subsection{Marketing Mix}

PT OAM in marketing activities using the principle of "Two-sided market" where the company's business serves two groups of interdependent customers (Rochet, J. C., \& Tirole, 2004). In very simple terms B2B means businesses that sell products or services to other businesses (Birks, 2016). This 4P concept is still relevant to be applied in the real of $\mathrm{B} 2 \mathrm{C}$. Relational marketing use NICE that consist of Networking, Interaction, Common Interest and Experience (Jony Oktavian Haryanto, 2007). In promotional activities PT OAM conveys unique value proposition or added value to customers, so they are will be interested and have reason to choose the product or service (Widardi et el., 2019).

\subsection{Sales}

PT OAM's marketing planning must be clearly, directed and connected with other parts, so that each activity becomes interconnected (Middleton et al., 2013). To carry out sales activities well, the sales team needs to be formed by recruiting competent people. This is necessary because, the sales team helped establish the relationship between sellers and buyers (Moon, M. \& Armstrong, 1994). In other words, sales team is a representative of the company in the eyes of partners. PT OAM arranges sales activities so that the sales process can be in line with the company's marketing objectives. Sales activities will encourage effectiveness, strengthen strategies and improve sales results (Zoltners et al., 2009).

\subsection{Revenue Stream Projection}

Revenue streams, describing how companies earn money from each customer segments. It is this flow of funds that keeps the company survives (Wardhanie, 2018).

\section{RESULT \& DISCUSSION}

Based on the description of marketing planning in the materials and methods above, the following are the results of marketing plan discussions at PT OAM.

\subsection{Marketing Objectives}

PT OAM will be conduct three stage of objectives that is short, mid and long term objectives as in Table 3.1 below.

Table 3.1 Marketing Objectives.

\begin{tabular}{|c|c|}
\hline Category & Marketing Objectives \\
\hline $\begin{array}{l}\text { Short-Term } \\
\text { (Y.0 to }<\text { Y.1) }\end{array}$ & $\begin{array}{l}\text { 1. Conducting product development in accordance with } \\
\text { market research } \\
\text { 2. Branding OAM companies offline and online } \\
\text { 3. Creating jamu partnerships through relationship marketing } \\
\text { strategies in West Java }\end{array}$ \\
\hline $\begin{array}{l}\text { Medium-Term } \\
\text { (Y.1 to Y.2) }\end{array}$ & $\begin{array}{l}\text { 1. Maximize branding through social media } \\
\text { 2. Creating jamu partnerships through relationship marketing } \\
\text { strategies in Java Island. }\end{array}$ \\
\hline $\begin{array}{l}\text { Long-Term } \\
(\mathrm{Y}>2)\end{array}$ & $\begin{array}{l}\text { 1. Expanding partnership business network throughout } \\
\text { Indonesia } \\
\text { 2. Maintaining good relationships with partners }\end{array}$ \\
\hline
\end{tabular}
Source: Author, 2021.

\subsection{Segmenting, Targeting, Positioning}

Segmentation taken by PT OAM in marketing partnership products focuses on Business to Business (B2B) where based on data data box 2020 the number of SMEs from year to year continues to increase by 64.2 million in 2018. From the data, it can be concluded that the desire of Indonesian people to be entrepreneurial through SMEs is very high. The number of pesantren in Indonesia is quite large. Based on data ditpdpontren.kemenag.go.id the number of pesantren in Indonesia until 26,974. The field of traditional health, especially jamu has not touched much to pesantrens. This allows PT OAM to make pesantren SMEs can be a segment for PT OAM. The hospital became one of the locations to develop medical tourism. Medical tourism is expected to integrate with traditional health services such as jamu. This is the basis of PT OAM to make the Hospital as a market segment. Networking with Perkumpulan Paricara Usada Indonesia (PPUIN) which is an organization that houses practitioners of traditional medicine in Indonesia, the organization members is segment of PT OAM. Targeting the marketing of PT OAM is micro and small non-agricultural SMEs engaged in the provision of accommodation 
and the provision of beverage food, active PPUIN members, pesantren under the auspices of Nahdlatul Ulama and General Hospitals. The achievement of the target is carried out gradually. as seen in table 3.2 below.

Table 3.2 Stages of Target Achievement.

\begin{tabular}{|l|l|l|l|l|l|}
\hline $\begin{array}{l}\text { Marketing } \\
\text { Target }\end{array}$ & Y1 & Y2 & Y3 & Y4 & Y5 \\
\hline SMEs & 50 & 100 & 200 & 400 & 600 \\
\hline Pesantren & 26 & 107 & 170 & 340 & 510 \\
\hline Hospital & 2 & 26 & 62 & 124 & 186 \\
\hline PPUIN & 8 & 24 & 15 & 30 & 45 \\
\hline \multicolumn{7}{|c|}{ Source: Author, 2021. }
\end{tabular}

PT OAM provides business package partnership jamu (Business Opportunity) in the form of cafes jamu or booths jamu. As a startup, PT OAM must compete hard with business ventures of similar partnerships in the field of jamu. Where its competitors provide more boiled jamu products that taste bitter and jamu sachets. In an effort to face competitors, to improve the image and precept of the community towards the partnership business of PT OAM, PT OAM determines positioning as a jamu partnership business that provides delicious, sweet and innovative jamu products with a cooperation scheme that is easy, fast and can use its own brand with provisions. PT OAM needs to make differentiation through taste, quality and price (Firmansyah et al., 2020). Positioning PT OAM looks like in figure 3.1 below.

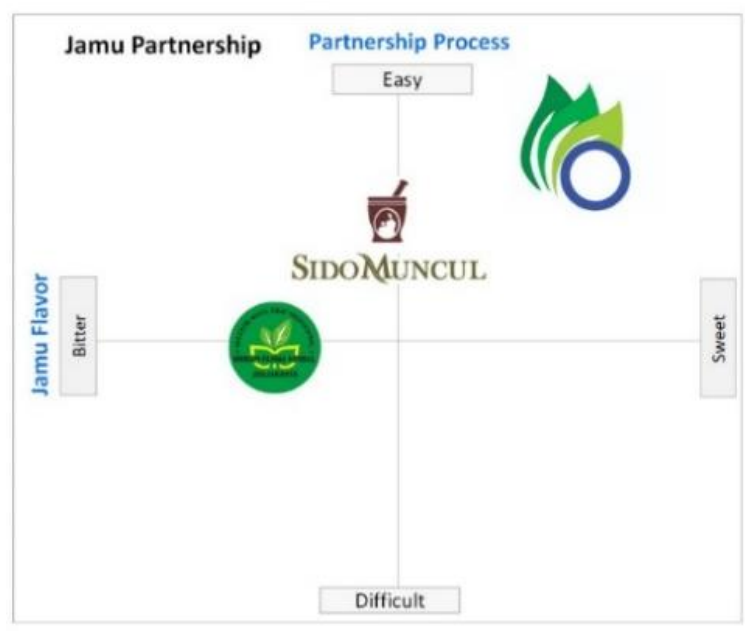

Figure 3.1 PT OAM Positioning. Source: Author, 2021.

\subsection{Marketing Mix}

Marketing mix that is the focus of PT OAM as a business that makes the target market Business to Business (B2B) is to use NICE, namely Networking, Interaction, Common Interest, and Experience.

\section{a. Networking}

Networking can be caused by one or a variety of factors. The longer the relationship is established, the more it will create a relationship that is not easy to break. PT OAM has a close relationship with PPUIN because one of the founders of PPUIN is a shareholder of PT OAM. Similarly, with Nahdlatul ulama pesantren, PT OAM got a recommendation from PBNU. RSPI Sulianti Saroso as the first hospital to establish a jamu café, giving positive word of mouth so that it can pave the way to enter the General Hospital. Healthy lifestyle trend back to nature brings PT OAM to target micro and small SMEs food and beverage providers who want to add or combine their business with jamu products.

\section{b. Interaction}

In conducting its business, PT OAM interacts with its employees as a form of closeness so that employees have loyalty to the company. PT OAM also engages with shareholders to discuss the company's development. Last but not least, interactions are built well with their partners, so that they become loyal customers while also being able to provide a positive word of mouth promotional effect.

\section{c. Common Interest}

PT OAM provides benefits to its partners where the benefit is not obtained by partners from other partnership businesses. Partners feel the benefits include the ease of cooperation scheme by giving flexibility to use their own brand namu by listing the logo of PT OAM. Jamu products are delicious, sweet and innovative to make partners able to compete with the latest beverage products. Mentoring is also done at the 
beginning of the partner pioneering the business.

\section{d. Experience}

As a startup in the field of business partnerships of course PT OAM must carry the concept of a strong partnership. Armed with the experience of making delicious jamu and human resources who have experience of jamu research, PT OAM created a partnership concept that presents jamu product with good taste, sweet and innovative. Not only that, the concept of relationship is also built to provide emotional bonding to partners so that it is not easy to switch to similar businesses but can complement when the partner already has a business in the field of food and beverage.

However, because PT OAM is a two-sided platform business that must pay attention to its end users, PT OAM also uses 7P marketing mix strategy (Product, Price, Promotion, Place, People, Process, Physical Evidence) to help its partners. The products provided are delicious, sweet and innovative jamu products (Products). Determine price of jamu by paying attention to the purchasing power of the middle and lower economic community and millennials (Price). Promosi using online and offline. Online promotions conducted using facebook media, instagram, webinars, youtube chanel,tiktok, and Whatsapp groups (Promotion). The partner's business location is in the cafeteria, cooperative and other strategic locations by using booths or café models (Place). To present jamu that is attractive and still has health benefits, each partner must have a minimum of one trained pramusodo (People). Pramusodo who has been trained, must apply Standar Operating Procedure (Process). Booths or cafes are designed with a traditional feel using wood. The characteristic is also displayed with Pramusodo's clothes, which feature kebaya on female pramusodo and Lurik clothes on men (Physical Evidence).

\subsection{Sales}

PT OAM sales activities are carried out thematically so that promotional costs are tailored to the monthly theme. To be able to carry out marketing activities, PT OAM formed a sales team (Sales Force), such as table 3.3 below.

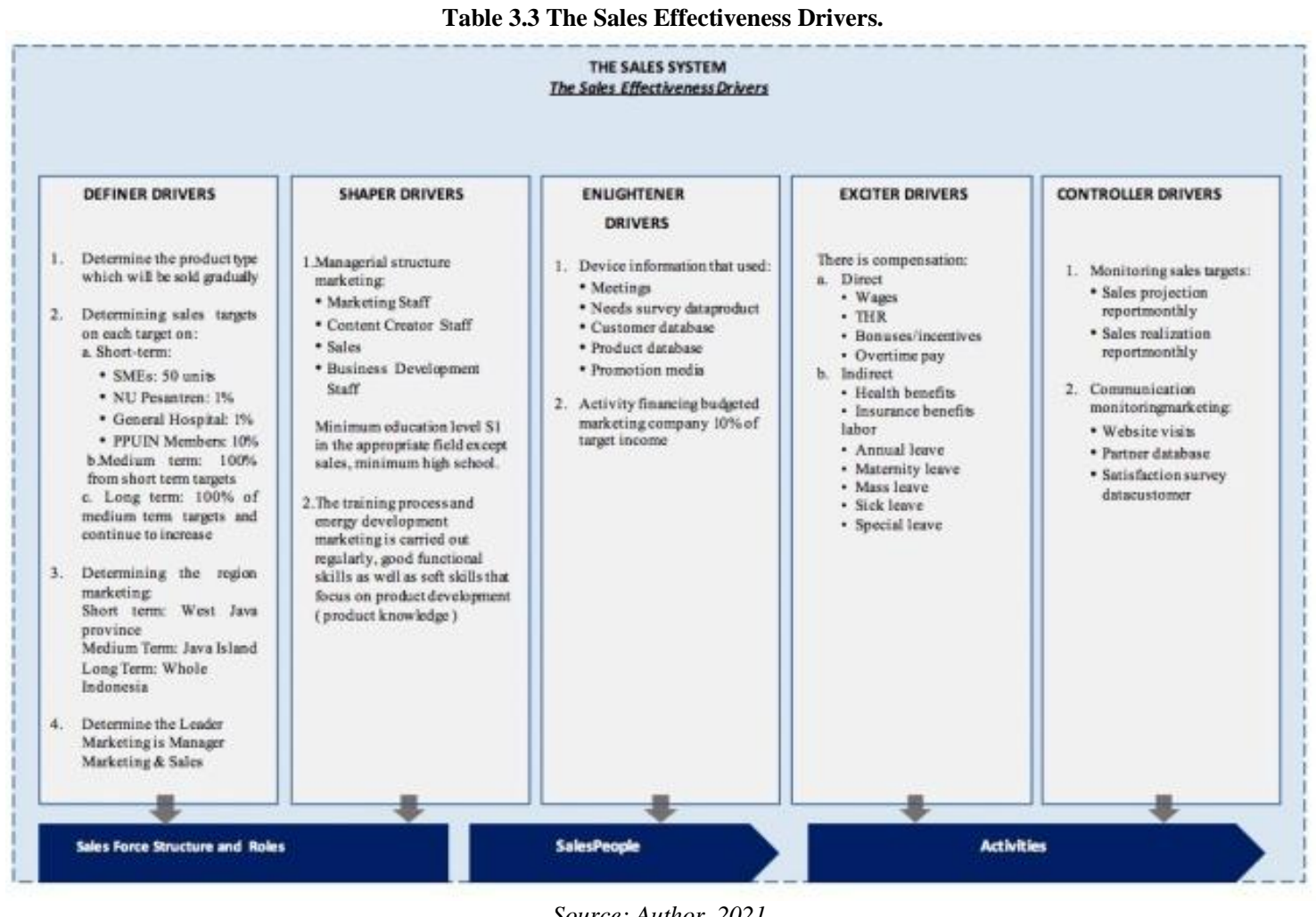

Source: Author, 2021. 


\subsection{Revenue Stream}

Revenue stream of PT OAM from the sale of partnership packages from new customers and the sale of repeat orders product packages from partners. Revenue stream PT OAM from the 1st year where the company is still preparing products and partnership design up to the 5 th year is assumed with a scenario based table 3.4 below.

\begin{tabular}{|c|c|c|c|c|c|c|c|}
\hline No & Assumption & Information & $\begin{array}{c}\text { Projection } \\
\text { Year } 1\end{array}$ & $\begin{array}{c}\text { Projection } \\
\text { Year } 2\end{array}$ & $\begin{array}{c}\text { Projection } \\
\text { Year } 3\end{array}$ & $\begin{array}{c}\text { Projection } \\
\text { Year } 4\end{array}$ & $\begin{array}{c}\text { Projection } \\
\text { Year } 5\end{array}$ \\
\hline 1 & $\begin{array}{l}\text { Product } \\
\text { development: has } \\
\text { a variant of } \\
\text { herbal medicine } \\
\text { products tasty } \\
\text { and sweet at least } \\
\text { three products in } \\
\text { the first year }\end{array}$ & $\begin{array}{l}\text { - Conducting market } \\
\text { research } \\
\text { - Compile research } \\
\text { reports } \\
\text { - Formulating a } \\
\text { product } \\
\text { - Screening of } \\
\text { maklon places } \\
\text { - Production of } \\
\text { sample products } \\
\text { - Test sample } \\
\text { products to market } \\
\text { - Product evaluation } \\
\text { - Massproduct } \\
\text { production } \\
\text { - Research up to } \\
\text { massproduct is } \\
\text { projected to be } \\
\text { completed about } 6 \\
\text { months in year I. } \\
\text { - Sales occurred in } \\
\text { the seventh month }\end{array}$ & $\begin{array}{l}\text { Products ar } \\
\text { prepare pro } \\
\text { managemen }\end{array}$ & $\begin{array}{l}\text { nade in a maklon } \\
\text { cttion equipment } \\
\text { formulas and ag }\end{array}$ & $\begin{array}{l}\text { i some partner he } \\
\text { - o only need to } \\
\text { ements) }\end{array}$ & $\begin{array}{l}\text { al medicine comy } \\
\text { repare warehous }\end{array}$ & $\begin{array}{l}\text { Inies (no need to } \\
\text { (include stock }\end{array}$ \\
\hline 2 & $\begin{array}{l}\text { Provision of } \\
\text { booth/café } \\
\text { design }\end{array}$ & Define booth/café design & \multicolumn{5}{|c|}{ Booth made by company / furniture industry partners (special product custome design } \\
\hline 3 & $\begin{array}{l}\text { Market } \\
\text { penetration: } \\
\text { Number of } \\
\text { partners on target }\end{array}$ & $\begin{array}{l}\text { The target market is } \\
\text { obtained from SMEs, } \\
\text { PPUIN. Pesantren NU, } \\
\text { General Hospital } \\
\text { Cooperative region: } \\
\text { Year I : West Java } \\
\text { Year II: Java Island } \\
\text { Year III sd V: All over } \\
\text { Indonesia }\end{array}$ & $\begin{array}{l}86 \text { partners: } \\
\text { SMEs : } 50 \\
\text { Pesantren: } 26 \\
\text { Hospital: } 2 \\
\text { PPUIN: } 8\end{array}$ & $\begin{array}{l}257 \text { partners: } \\
\text { SMEs: } 100 \\
\text { Pesantren: } 107 \\
\text { Hospital: } 26 \\
\text { PPUIN: } 24\end{array}$ & $\begin{array}{l}\text { 447 partners: } \\
\text { SMEs: } 200 \\
\text { Pesantren: } 170 \\
\text { Hospital: } 62 \\
\text { PPUIN: } 15\end{array}$ & $\begin{array}{l}894 \text { partnerts: } \\
\text { SMEs: } 400 \\
\text { Pesantren: } 340 \\
\text { Hospital: } 124 \\
\text { PPUIN: } 30\end{array}$ & $\begin{array}{l}\text { 1.341 partners: } \\
\text { SMEs: } 600 \\
\text { Pesantren: } 510 \\
\text { Hospital: } 186 \\
\text { PPUIN: } 45\end{array}$ \\
\hline$\overline{4}$ & $\begin{array}{l}\text { Partnership } \\
\text { Package } \\
\text { Revenue }\end{array}$ & $\begin{array}{l}\text { The price of each package } \\
\text { varies: } \\
\text { C-OAM 1: Rp 17.000.000,- } \\
\text { C-OAM 2: Rp 26.000.000,- } \\
\text { C-OAM 3: Rp 50.000.000,- } \\
\text { C-OAM 4: Rp } \\
100.000 .000,-\end{array}$ & $\begin{array}{l}\text { Number of } \\
\text { partnership } \\
\text { packages: } \\
\text { C-OAM 1:49 } \\
\text { COAM 2: } 29 \\
\text { C-OAM 3:6 } \\
\text { C-OAM 4:2 }\end{array}$ & $\begin{array}{l}\text { Number of } \\
\text { partnership } \\
\text { packages: } \\
\text { C-OAM 1:123 } \\
\text { COAM 2: } 64 \\
\text { C-OAM 3:55 } \\
\text { C-OAM 4:15 }\end{array}$ & $\begin{array}{l}\text { Number of } \\
\text { partnership } \\
\text { packages: } \\
\text { C-OAM 1:193 } \\
\text { COAM 2: } 134 \\
\text { C-OAM 3:70 } \\
\text { C-OAM 4:50 }\end{array}$ & $\begin{array}{l}\text { Number of } \\
\text { partnership } \\
\text { packages: } \\
\text { C-OAM 1:386 } \\
\text { COAM 2: } 268 \\
\text { C-OAM 3:140 } \\
\text { C-OAM 4:100 }\end{array}$ & 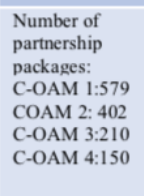 \\
\hline 5 & $\begin{array}{l}\text { Repeat Order } \\
\text { (RO) Revenue }\end{array}$ & $\begin{array}{l}\text { Worth the price of package } \\
\text { product C-OAM } 1 \rightarrow \text { Rp } \\
1,220,000 \text { - in } 1 \text { time a } \\
\text { month repeat order }\end{array}$ & $\begin{array}{l}\text { Total RO: } 143 \\
\text { product } \\
\text { packages }\end{array}$ & $\begin{array}{l}\text { Total RO: } \\
2,464 \text { product } \\
\text { packages }\end{array}$ & $\begin{array}{l}\text { Total RO: } \\
6,712 \text { product } \\
\text { packages }\end{array}$ & $\begin{array}{l}\text { Total RO: } \\
15,032 \\
\text { product } \\
\text { packages }\end{array}$ & $\begin{array}{l}\text { Total RO: } \\
28,467 \text { product } \\
\text { packages }\end{array}$ \\
\hline
\end{tabular}

\section{CONCLUSION}

As a startup company in the field of jamu partnerships, to be able to compete with competitors, PT OAM must have marketing planning by paying attention to internal and external factors. Choosing the right strategy will bring the company to continue to grow and generate revenues that continue to increase every year. Segmenting strategies must be directed. The target customer must be clear. So that the human resources owned by the company can work efficiently and effectively. Companies should also be able to take the right positioning to attract customers and minimize competition.
PT OAM in marketing partnership products focuses on Business to Business (B2B). Nice's strategy would be more appropriate to use on B2B consumers. However, as a company with a two sided platform, the $7 \mathrm{P}$ concept can complement the NICE scheme in order to touch the end user. In nice strategy, networking is the main thing in running this strategy. Without strong networking, it is difficult for companies to get B2B customers. Sales activities should also be able to consider with the resources owned by both the sales team and costs in order to carry out all marketing activities in accordance with the strategy set in order to achieve sales targets so as to generate profit for the company. 
Acknowledgement: None

\section{Conflict of Interest: None}

\section{Source of Funding: None}

\section{REFERENCES}

1. Andayani, A., Nuh, A., Syah, T. Y. R., Indradewa, R., \& Fajarwati, D. (2020). Free Delivery Serving and Religious Issue to Enhance Local Retail Competitiveness Facing National Minimarket. Journal of Multidisciplinary Academic, 04(03), 187189. Retrieved from http://www.kemalapublisher.com/index.php /JoMA/article/view/466.

2. Arifin, F. A. S., Yanuar, T., Syah, R., Indradewa, R., \& Pusaka, S. (2019). Sales and Marketing Strategies Duck Nugget Product Using Porter's Five Force and SWOT Analysis. Journal of Multidisciplinary Academic, 03(04).

3. Birks, D. F. (2016). Marketing research. In The Marketing Book: Seventh Edition. https://doi.org/10.4324/9781315890005.

4. Calkins, T. (2012). Breakthrough marketing plans: How to stop wasting time and start driving growth. Palgrave Macmillan.

5. Firmansyah, M. R., Yanuar R. Syah, T., Semerdana, P., \& Ramdhani, D. (2020). Marketing Plan Implementation over Business Start-up: Food Combining at PT. Beras Jagung Nusantara. Journal of Multidisciplinary Academic, 4(2), 86-89. (2), 86-89.

6. Harackiewicz, J. M., Durik, A. M., Barron, K. E., Linnenbrink-Garcia, L., \& Tauer, J. M. (2008). The role of achievement goals in the development of interest: reciprocal relations between achievement goals, interest, and performance. Journal of educational psychology, 100(1), 105.

7. Jony Oktavian Haryanto. (2007). Beyond Marketing Book, Growth and Sustainability.

8. Middleton, V., Fyall, A., Morgan, M., \& Ranchhod, A. (2013). Marketing in travel and tourism. New York, NY: Routledge.

9. Mombeuil, C., \& Fotiadis, A. K. (2017). Assessing the effect of customer perceptions of corporate social responsibility on customer trust within a low cultural trust context. Social Responsibility Journal, Vol. 13, pp. 698-713. https://doi.org/10.1108/SRJ-02-2017-0032.

10. Moon, M. \& Armstrong, G. (1994). Selling teams: A conceptual framework \& research agenda. Journal of Personal Selling and Sales Management. 14, 17-30.

11. Morris, M. H., Schindehutte, M., \& LaForge, R. W. (2002). Entrepreneurial marketing: a construct for integrating emerging entrepreneurship and marketing perspectives. Journal of marketing theory and practice, 10(4), 1-19. https://doi.org/10.1080/10696679.2002.115 01922.

12. Rochet, J. C., \& Tirole, J. (2004). Twosided markets: an overview. Institut d'Economie Industrielle working paper.

13. Rowson, P. (2009). Putting it all together Your marketing plan. Richmond, VI Crimson Business Ltd. The Emerald Handbook of Entrepreneurship in Tourism, Travel and Hospitality.

14. Wardhanie, A. P., \& Kumalawati, D. (2018). Analisis business model canvas pada perpustakaan Institut Bisnis dan Informatika Stikom Surabaya dalam meningkatkan kualitas perguruan tinggi. Berkala Ilmu Perpustakaan Dan Informasi, 14(2), 124. https://doi.org/10.22146/bip.32247.

15. Widardi, J., Yanuar, T., Syah, R., Indradewa, R., \& Pusaka, S. (2019). Marketing Mix Strategy Implementation for Business Plan at LH Hotel. Science, Engineering and Social Science Series, 3(5), 167-168. Retrieved from http://www.kemalapublisher.com/index.php /JoMA/article/view/415.

16. Zoltners, A. A., Sinha, P., \& Lorimer, S. E. (2009). Building a winning sales force: Powerful strategies for driving high performance. Amacom Div American Mgmt Assn.

How to cite this article: Setiyawati E, Indradewa R, Syah TYR et.al. Marketing plan for business startups "jamu partnership" in Indonesia. International Journal of Research and Review. 2021; 8(8): 327-333. DOI: https://doi.org/10. 52403/ijrr.20210845 